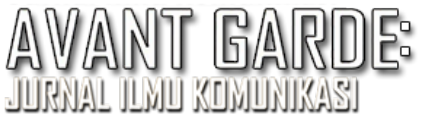

\title{
Konstruksi Identitas Masyarakat Dayak Melalui Budaya Baroah Dalam Membangun Citra Desa Sompak di Kabupaten Landak
}

\author{
Sonia Glory Desinta; Rini Darmastuti \\ e-mail: sgdesinta@gmail.com; rini.darmastuti@uksw.edu \\ Universitas Kristen Satya Wacana
}

Submitted: 07 December 2019 Revised: 14 December 2019 Accepted: 19 December 2019

\begin{abstract}
Abstrak
Salah satu kekayaan budaya Indonesia adalah budaya Baroah yang dimiliki oleh suku Dayak Kanayatn khususnya, khususnya di desa Sompak. Ucapan syukur dan penghormatan kepada sang Maha Pencipta merupakan ekspresi dari budaya Baroah yang dilakukan secara turun menurun. Ekspresi dari setiap budaya, mengkonstruksi identitas suatu masyarakat yang mempengaruhi persepsi orang lain terhadap masyarakat dan daerah dimana mereka berada, dan berdampak pada citra daerah tersebut. Berdasarkan pemikiran ini, yang menjadi tujuan dari tulisan ini adalah mengkonstruksi identitas diri masyarakat desa Sompak melalui budaya Baroah, sebagai strategi membangun citra kabupaten Landak. Tulisan ini didasarkan dari hasil penelitian yang dilakukan dengan menggunakan metode kualitatif dan pendekatan Etnografi, serta wawancara mendalam dan observasi kepada ketua dewan adat dayak kecamatan Sompak, ketua dewan adat desa Sompak dan ketua petani desa Sompak. Hasil dari penelitian ini adalah a). Budaya Baroah adalah ucapan syukur kepada Jubata atas hasil panen padi, kesehatan dan terhindar dari bencana serta didalamnya ada suatu ritual Nyangahatn yang mengandung doa-doa dan mengajarkan kita harus menghormati adat, tradisi dan terutama Jubata, karena semua yang dimiliki manusia berasal dari Tuhan. b). Identitas Masyarakat desa Sompak membentuk citra sebagai masyarakat yang berpegang teguh pada adat istiadat.
\end{abstract}

Kata kunci: Budaya Baroah, citra, konstruksi identitas, masyarakat Dayak

\begin{abstract}
One of the assets of culture in Indonesia is Baroah culture from Dayak Kanayatn, which located in Sompak village. Thanksgiving and respect to the god are the expressions from the Baroah culture, which is done from generation to generation. The expression of each culture, constructs the identity of a society that influences other people's perceptions of the community and the area where they are, and has an impact on the image of the region. Based on this perspective, the purpose of this paper is constructs the identity of Sompak village people from Baroah culture, as a strategy to build the image of the Landak district.This paper is based on the results of research conducted using qualitative methods and ethnographic approaches, as well as in-depth interviews and observations to the head of the Sompak sub-district customary council, the head of the Sompak village traditional council and the head of the Sompak village farmers. The result of this paper are : a). Baroah culture is a thanksgiving to Jubata for the rice harvest, health and avoiding disaster and in it there is a Nyangahatn ritual that contains prayers and teaches us to respect customs, traditions and especially Jubata, because everything that humans have comes from God, b). Identity The people of Sompak Village made an image as a society that holds into tradition.
\end{abstract}

Keywords: Identity construction, Baroah Culture, Dayak Society, Image

\section{PENDAHULUAN}

Indonesia adalah negara yang
memiliki ciri khas tersendiri yang
membedakannya dari negara-negara lain.

Beraneka ragam suku dan budaya yang ada di Indonesia, menjadi salah satu ciri khas masyarakat Indonesia. Setiap pulau di Indonesia memiliki beberapa suku dengan 
adat istiadat yang beragam. Kalimantan adalah salah satu pulau terbesar di Indonesia dengan keberagaman suku dan budaya. Salah satu suku yang mendiami pulau tersebut adalah Suku Dayak. Masyarakat Dayak adalah masyarakat yang memiliki banyak tradisi dan adat istiadat seperti daerah lainnya di Indonesia. Akan tetapi belum banyak masyarakat yang tahu tentang keragaman kebudayaan yang dimiliki masyarakat Dayak, sehingga banyak orang yang masih asing ketika mendengar tentang keanekaragaman kebudayaan Dayak. Suku Dayak Kanayatn adalah salah satu subculture terbesar dari 459 sub-culture Dayak di Kalimantan, yang masih memegang erat warisan budaya dari pendahulunya. Suku Dayak Kanayatn ada di Kabupaten Landak, Provinsi Kalimantan Barat.

Sebagai daerah yang kaya dengan budaya dan tradisi dari nenek moyangnya, Kabupaten Landak memiliki banyak tradisi dan warisan budaya sebagai identitas daerah tersebut. Salah satu tradisi dan warisan budaya tersebut adalah perayaan Naik Dango. Pada saat ini, tradisi Naik Dango dalam pelaksanaannya sudah dimodernisasi. Tradisi Naik Dango dilaksanakan setiap tahun di Rumah Radakng Aya' yang berlokasi di Kecamatan Ngabang Kabupaten Landak. Ritual Naik Dango yang dilaksanakan secara modern ini, tidak lagi menggunakan ritual secara utuh seperti tradisi yang dilakukan selama ini. Ritual Naik Dango dimodifikasi pelaksanaannya dan pada setiap upacaranya selalu dimeriahkan oleh perlombaan-perlombaan berupa kesenian adat dari daerah berbeda di Kabupaten tersebut (Priskila, 2010:30).
Dari beragam tradisi yang dimiliki oleh Suku Dayak Kanayatn khususnya di Kabupaten Landak, ada satu tradisi yang cukup dikenal oleh masyarakat Dayak Kanayatn, yaitu Tradisi Baroah. Tradisi Baroah masih dilakukan hingga saat ini di Kabupaten Landak terkhusus di desa Sompak. Baroah adalah tradisi tahunan yang tetap dikenal di kalangan masyarakat suku Dayak Kanayatn. Tradisi Baroah merupakan ritual yang dilakukan sebagai wujud ungkapan rasa syukur kepada Jubata (Tuhan YME) yang telah memberikan hasil melimpah pada usaha pertanian yang dilakukan. Tradisi ini masih menyangkut nilai-nilai religius yang termasuk dalam unsur kebudayaan. Sistem religi merupakan wujud sistem keyakinan dan gagasan-gagasan tentang Tuhan, dewa-dewa, roh-roh halus, neraka, sorga, dan sebagainya. Sistem religi juga berwujud upacara-upacara, baik yang bersifat musiman maupun yang kadangkala (Koentjaraningrat,1986:204).

Pada tradisi Barokah dilakukan panen uma yaitu memanen hasil berladang yang berlangsung setiap tahunnya pada bulan April hingga bulan Mei. Secara umum, tradisi ini sudah ditetapkan dalam kalender pertanian masyarakat Dayak Kanayatn dan dilaksanakan pada akhir bulan April, antara tanggal 27-30 setiap tahunnya. Tradisi tahunan ini dikemas dalam bentuk sebuah pesta besar yang melibatkan banyak kalangan, baik dari pihak tuan rumah (tempat dilaksanakannya tradisi ini) maupun masyarakat atau instansi-instansi yang diundang. Tradisi dilakukan pada bulan April karena pada bulan April Suku Dayak Kanayatn yang sebagian besar berpenghasilan sebagai petani menunaikan panen tahunan (Andasaputra dalam Priskila, 2010:3). 
Pada era modern saat ini, Suku Dayak Kanayatn, khususnya masyarakat di Desa Sompak, masih memelihara tradisi warisan leluhur seperti halnya memperingati tradisi Baroah setiap tahunnya. Tradisi ini membentuk keyakinan masyarakat Dayak Kanayatn, yang mempercayai bahwa bila upacara ini dilaksanakan maka masyarakat akan memperoleh keselamatan. Pelaksanaan tradisi ini seringkali dihadiri oleh perwakilan pemerintahan daerah, para tetua adat, tokoh-tokoh masyarakat, seperti bupati, camat, kepala desa dan lainnya. Cara penyampaian pesan untuk mengundang tokoh masyarakat masih menggunakan Bahasa Dayak Kanayatn yang dimiliki oleh masyarakat di daerah tersebut. Bahasa Dayak Kanayatn merupakan salah satu bahasa dari berbagai macam bahasa dari Suku Dayak di Kalimantan Barat, dan bahasa inilah yang digunakan oleh masyarakat di Desa Sompak. Bahasa Dayak Kanayatn sudah dijadikan sebagai bahasa pemersatu untuk menjalin komunikasi satu dengan lainnya, dalam hal menyampaikan suatu pesan, mengabarkan suatu acara, maupun pelaksanaan suatu acara di Desa Sompak dari zaman nenek moyang. Dan sampai sekarang, Bahasa Dayak Kanayatn ini masih digunakan oleh masyarakat untuk berkomunikasi dalam kehidupan seharihari, baik oleh para orang tua, tokoh masyarakat, kaula muda, maupun anakanak dalam suatu komunikasi yang terjalin.

Pelaksanaan tradisi Baroah serta penggunaan Bahasa Dayak Kanayatn dalam kehidupan sehari-hari dan pada saat menyampaikan pesan ketika mengundang tokoh masyarakat untuk menghadiri ritualritual tradisional merupakan suatu keunikan pada era modern ini. Di tengah gempuran teknologi dan budaya asing yang hadir di tengah masyarakat, Bahasa Dayak Kanayatn masih tetap digunakan masyaraat di Desa Sompak dan mempersatukan mereka. Bahasa menjadi alat yang mempersatukan mereka dan membangun kedekatan antara yang satu dengan yang lain. Bahasa merupakan wahana komunikasi utama manusia yang memiliki empat fungsi, yaitu sebagai pengenal (identifies), sebagai wahana interaksi sosial, sebagai katarsis, sebagai manipulatif (Arnold dan Hirsch dalam Lagu, 2016:4). Selain sebagai alat pemersatu, Bahasa Dayak Kanayatn juga menjadi identitas bagi masyarakat di Desa Sompak.

Identitas seperti bahasa maupun tradisi memiliki makna pada budaya yang diciptakan oleh masyarakat tersebut. Identitas merupakan karakter khusus yang melekat pada setiap kebudayaan, yang akhirnya dapat digunakan untuk membedakan antara kebudayaan satu dengan kebudayaan lainnya. Menurut Fong, sebagaimana dikutip oleh Samovar (dalam Tamburian, 2018:80), identitas budaya dapat diamati dari "identifikasi komunikasi dari sistem perilaku simbolis verbal dan non-verbal yang memiliki arti dan yang dibagikan diantara anggota kelompok yang memiliki rasa saling memiliki dan yang membagi tradisi, warisan, bahasa, dan norma-norma yang sama. Identitas budaya merupakan konstruksi sosial”. Suatu kebudayaan yang menjadi sebuah identitas suatu masyarakat tidak muncul atau tercipta begitu saja, melainkan perlu waktu lama untuk diakui, diketahui dan diimplementasikan dalam kehidupan. Identitas yang dimiliki 
oleh setiap kebudayaan adalah karakteristik dari kebudayaan tersebut.

Proses ini juga yang terjadi di masyarakat di Desa Sompak. Identitas dari masyarakat di Desa Sompak ini sangat dipengaruhi oleh budaya di mana mereka hidup. Identitas ini juga dipengaruhi oleh Bahasa yang mereka gunakan, baik secara verbal dan nonverbal. Sistem yang digunakan menjadi pembeda antara kelompok mereka dengan kelompok lainnya. Suatu budaya membawa suatu kebiasaan yang khas dari tiap daerah dan menjadi identitas bagi masyarakat yang menghidupi budaya tersebut. Seperti halnya masyarakat di Desa Sompak, Bahasa Dayak Kanayatn yang mereka gunakan dalam kehidupan sehari-hari, serta tradisi Baroah yang terus mereka hidupi, menjadi identitas bagi masyarakat di desa ini. Dalam era modern, penggunaan Bahasa daerah dalam kehidupan sehari-hari serta tradisi dan ritual yang terus dihidupi, menjadi satu keunikan yang perlu dikaji. Berdasarkan latar belakang ini, yang menjadi pertanyaan kemudian adalah identitas apa yang terbentuk dalam kehidupan masyarakat di Desa Sompak melalui pesan-pesan dalam Budaya Baroah? Bagaimana identitas masyarakat desa Sompak ini membentuk citra desa tersebut?

Berdasarkan dua pertanyaan itulah maka penulis melakukan penelitian dengan judul, "Konstruksi Identitas Masyarakat Dayak Kabupaten Landak Melalui Budaya Baroah dalam Rangka Membangun Citra Desa Sompak di Kabupaten Landak" sebagai dasar dalam penulisan artikel ini.

\section{METODE PENELITIAN}

Tulisan ini didasarkan dari hasil penelitian yang dilakukan dengan menggunakan metode deskriptif kualitatif. Deskripsi kualitatif mempersyaratkan suatu usaha dengan keterbukaan pikiran untuk merumuskan subjek yang sedang diteliti ataupun yang dialaminya (Spielgelberg dalam Simbolon, 2012:46). Pendekatan yang digunakan adalah pendekatan Etnografi. Etnografi adalah deskripsi atau interpretasi dari satu grup budaya, sosial atau sistem. Pada tataran ini, peneliti meneliti pola tingkah laku, kebiasaan-kebiasaan serta cara-cara hidup kelompok yang sedang diamati. Brewer (2000 : 10) mengatakan Etnografi merupakan studi tentang individu-individu yang diamati dalam kondisi yang netral dan alami dengan menggunakan metode yang berusaha menangkap makna sosial dan kegiatan sehari-hari. Menurut Spradley (dalam Manab, 2008:67) penelitian kualitatif dengan pendekatan etnografi, adalah penelitian yang berusaha mencari apa yang dilakukan orang-orang (perilaku), apa yang mereka katakan (bahasa), dan beberapa ketegangan antara apa yang benar-benar mereka lakukan dan yang seharusnya mereka lakukan serta apa yang mereka buat dan gunakan (artefak).

Teknik pengumpulan data pada penelitian ini adalah wawancara mendalam kepada key informan sehingga didapatkan data yang kredible dan bisa dipertanggungjawabkan. Wawancara mendalam merupakan wawancara yang dilakukan dengan lentur dan terbuka, tidak berstruktur ketat, dan tidak dalam suasana formal. Key informan dalam peneliti ini adalah Seselius selaku ketua dewan adat Kecamatan Sompak, Feri selaku Ketua Dewan Adat desa Sompak, dan Acin 
selaku kepala kelompok tani di desa Sompak. Teknik analisis data dalam penelitian ini adalah teknik Etnografis. Menurut Spradley (dalam Nugrahani, 2014:178), analisis etnografis dengan berbagai tipe pertanyaannya sesungguhnya mempunyai satu tujuan yang sama, yaitu mengungkapkan sistem makna budaya yang digunakan oleh masyarakat.

\section{HASIL DAN PEMBAHASAN}

Konstruksi sosial yang terjadi di masyarakat di desa Sompak tidak terjadi di dalam ruang hampa, tetapi sarat dengan kepentingan-kepentingan. Proses dalam konstruksi sosial ini terjadi dalam beberapa tahapan, yaitu tahap eksternalisasi, tahap objektivasi dan tahap internalization. Identitas masyaraat di desa Sompak, dikonstruksi secara sosial melalui lensa budaya dengan menggunakan media komunikasi. Hecht (Littlejohn dan Foss, 2012 : 132) mengatakan, identitas kita adalah 'kode' yang mendefinisikan keanggotaan kita dalam masyarakat yang beragam. Kode ini terdiri dari simbolsimbol yang digunakan dalam kehidupan sehari-hari seperti pakaian dan kepemilikan, kata-kata yang dipilih untuk mendiskripsikan diri mereka sendiri, atau barang yang biasanya dikatakan oleh masyarakat, serta makna yang mereka hubungkan dengan benda-benda tersebut.

Dalam proses pembentukan identitas, komunikasi mempunyai peranan yang sangat penting sebagai alat untuk membentuk identitas serta mengubah mekanisme. Identitas suatu masyarakat sangat dipengaruhi oleh banyak faktor, salah satunya adalah identitas budaya. Proses pembentukan identitas masyarakat di Desa Sompak, Kabupaten Landak sangat dipengaruhi oleh komunikasi yang mereka lakukan. Artinya, komuniksi mempunyai peranan yang sangat penting dalam membentuk identitas dan mengubah mekanisme masyarakat di desa Sompak. Selain itu, identitas masyarakat di Desa Sompak ini juga dipengaruhi oleh budaya yang mereka hidupi, salah satunya adalah Budaya Baroah. Yang menjadi pertanyaan kemudian adalah bagaimana pesan-pesan dalam Budaya Baroah itu membentuk identitas masyarakat di Desa Sompak?

\section{Identitas masyarakat di desa Sompak melalui pesan-pesan dalam budaya Baroah}

Koentjaraningrat mengatakan bahwa "kebudayaan" berasal dari kata Sansekerta buddhayah bentuk jamak dari buddhi yang berarti budi atau akal, sehingga menurutnya kebudayaan dapat diartikan sebagai hal- hal yang bersangkutan dengan budi dan akal, ada juga yang berpendapat sebagai suatu perkembangan dari majemuk budi- daya yang artinya daya dari budi atau kekuatan dari akal (Mahalli, 2016). Hal tersebut memberikan makna bahwa budaya mencakup semua yang didapatkan dan dipelajari dari pola berpikir, cara, merasakan dan juga bertindak. Budaya merupakan suatu yang komplek yang terdiri dari pengetahuan, kepercayaan, moral, hukum dan kebiasaan lainnya yang dilakukan oleh seseorang sebagai anggota masyarakat. Hal ini seperti yang dikatakan oleh Sir Edward Burnett Tylor,

Culture is that complex whole which includes knowledge, belief, art, morals, law, custom and any other capabilities and habits acquired by man as a member of society' (Sir Edward, 2010 dalam Samovar, Porter dan Daniel 2012 : 10). 
Dalam kehidupan masyarakat di Desa Sompak, budaya yang mereka hidupi merupakan suatu yang kompleks yang terdiri dari pengetahun, kepercayaan, moral, hukum atau kebiasaan lainnya yang didapat dan dipelajari dari pola berpikir, cara merasakan dan juga bertindak. Salah satu budaya yang tetap dihidupi oleh masyarakat di Desa Sompak adalah budaya Baroah. Budaya Baroah merupakan suatu ritual yang dilakukan sebagai cara untuk menyatakan ucapan syukur kepada Jubata, atas segala hal yang dilimpahkan kepada masyarakat di Desa Sompak. Ritual ini dilakukan untuk menyataan ucapan syukur tentang hasil panen yang padi yang melimpah, ucapan syukur atas kesehatan dan ucapan syukur atas kebebasan dari bencana.

$\mathrm{Fe}$ dalam wawancara mendalam pada tanggal 22 Oktober 2019 mengatakan,

"Baroah koa dilaksanakan karena diri' koa ngucapatn syukur ka Jubata, syukur atas samuanya. Karena Jubata koalah nang mare diri idup" (Baroah itu dilaksanakan dikarenakan kita (masyarakat desa Sompak) mengucapkan syukur kepada Tuhan, bersyukur atas semuanya. Karena Tuhan itulah yang memberikan kita semua hidup).

Tradisi Baroah merupakan ritual yang dilakukan sebagai wujud ucapan syukur kepada Jubata atas panen padi yang berlimpah yang diberikan kepada petani di Desa Sompak. Hal ini seperti yang diungkapkan Ac, narasumber kedua dalam penelitian ini, pada saat wawancara mendalam pada tanggal 25 Oktober 2019,

"Baroah ngian acara untuk ngucapatn syukur karna Panen Padi diri' samua ka kampong nian. Diri' ngungkapkan syukur uga ka'Jubata karena dimare' manyak hasil panen padi dari samua petani $k a$ kampong nian" (Baroah ini adalah acara untuk mengucapkan syukur karena panen padi kita semua di kampung ini. Kita mengungkapkan syukur juga kepada Jubata karena diberi banyak hasil panen padi, dari semua petani di kampung ini)

Selain sebagai wujud ucapan syukur atas segala karunia dan atas hasil panen yang melimpah, tradisi Baroah dilakukan sebagai ritual untuk menyampaikan ungkapan syukur atas kesehatan yang diberikan dan kebebasan dari bencana yang diberikan untuk masyarakat di desa Sompak. Hal ini seperti yang dikatakan SS dalam wawancara mendalam pada tanggal 29 Oktober 2019,

"Baroah ngian diri"

laksanakan karena diri koa ngucapatn syukur ka'Jubata atas panen padi nang berlimpah, kesehatan nang dah dimare dan juga dah dinyauhatn dari bencana oleh Jubata" (Baroah ini kita laksanakan karena kita itu mengucapkan syukur kepada Jubata atas panen padi yang berlimpah, kesehatan yang sudah diberikan dan juga sudah dijauhkan dari bencana oleh Tuhan)

Mengacu dari pendapat Gudykunst and Kim, tradisi Baroah merupakan budaya yang diturunkan dari satu generasi kepada generi berikutnya dan sebagai transfer pengetahuan dan kearifan lokal yang dimiliki oleh nenek moyang masyarakat Dayak di Desa Sompak. Gudykunst and Kim (1992 dalam Tubbs dan Sylvia, 2008 : 19) memberikan 
pengertian tentang budaya sebagai cara hidup yang dikembangkan dan dimiliki oleh sekelompok orang dan kemudian diwariskan dari generasi yang satu ke generasi berikutnya. Dengan kata lain, budaya merupakan cara hidup yang terus diajarkan dan ditransferkan kepada generasi berikutnya. Tujuannya adalah supaya ajaran dari budaya itu tetap dihidupi oleh generasi berikutnya. Hal inilah yang membuat budaya itu tetap tidak punah. Hal ini juga yang terjadi dengan tradisi Baroah. Tradisi yang dilakukan sebagai bentuk ucapan syukur kepada Jubata, sumber dari segala sumber kehidupan, terus diajarkan oleh masyarakat Dayak Kanayatn di desa Sompak, dari satu generasi kepada generasi berikutnya sebagai usaha untuk melestarikan budaya yang mereka miliki.

Menurut SS, salah satu keyperson dari penelitian yang dilakukan oleh penulis, dalam wawancara mendalam pada tanggal 29 Oktober 2019 mengatakan,

"Acara nian tradisi urakng diri' dari jaman de'e sampe ampeatn diri' ikuti" (Acara ini adalah tradisi masyarakat Sompak dari jaman dahulu hingga sekarang kita ikuti)

Hal serupa juga disampaikan oleh Ac dalam wawancara mendalam pada tanggal 25 Oktober 2019,

"Untuk melestariatn tradisi Budaya nang udah dari de'e jadi tradisi masyarakat diri' ka kampokng nian" (Untuk melestarikan tradisi Budaya yang sudah dari dulu menjadi tradisi masyarakat kita di kampung ini)

Ucapan syukur dalam Tradisi Baroah ini, dilakukan dalam rangkaian upacara, yang dilengkapi dengan sajian yang sudah dipersiapkan. yang dilakukan dalam melakukan ritual dan juga ada sajian yang dipersiapkan. Upacara ritual atau ceremony adalah sistem aktifitas atau rangkaian tindakan yang ditata oleh adat atau hukum yang berlaku dalam masyarakat yang berhubungan dengan berbagai macam peristiwa yang biasanya terjadi dalam masyarakat yang bersangkutan (Koentjaraningrat dalam Ngare, 2014). Bagi masyarakat Dayak Kanayatn di Desa Sompak, Nyangahatn adalah ritual yang dilakukan dengan tata cara yang diatur dalam adat yang berlaku di masyarakat desa Sompak dengan melakukan pengucapan doa-doa. Ada makna dari setiap pesan pada saat melakukan ritual Nyangahatn. Narasumber Fe (dalam wawancara mendalam pada tanggal 22 Oktober 2019) mengatakan,

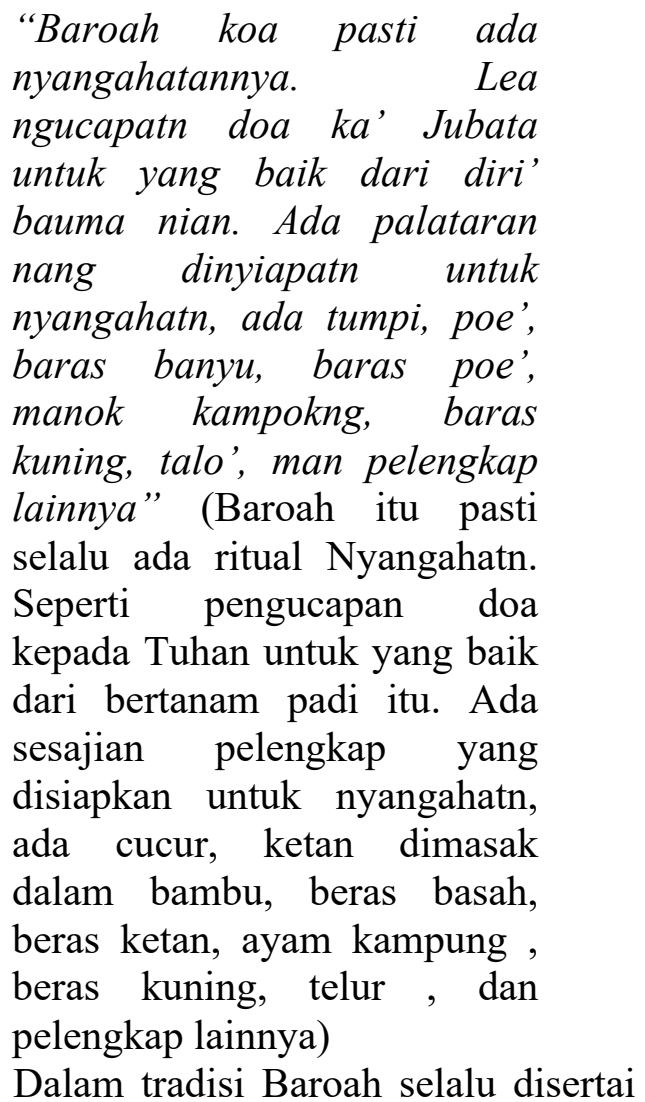
dengan ritual Nyangahatn sebagai ungkapan syukur kepada Tuhan yang dilengkapi dengan sesajian untuk Nyangahatn yang terdiri dari cucur, ketan 
dimasak dalam bambu, beras basah, beras ketan, ayam kampung, beras kuning, telur dan pelengkap lainnya. Dalam ritual Nyangahatn, ada doa-doa yang disampaikan kepada Jubata. Ritual tersebut dilakukan oleh seorang medium yang disebut Panyangahatn. Hal ini disampaikan oleh narasumber SS bahwa Ritual Budaya Baroah itu dilakukan oleh panyangahatn yang menjadi perantara. Narasumber SS dalam wawancara mendalam pada tanggal 29 Oktober 2019 mengatakan,

"Panyangahatn nian adalah urakng nang ngucapan doa doa dalam Bahasa diri, nianlah nang jadi perantara antara diri talino man Jubata" (Panyangahatn ini adalah orang yang mengucapkan doadoa daam Bahasa Dayak, inilah yang menjadi perantara antara manusia dengan Tuhan)

Doa yang disampaikan oleh Panyangahatn merupakan wujud ungkapan terimakasih kepada Jubata. Dalam Budaya Baroah, ada pelaksanaan survei lokasi penanaman untuk memastikan lahan akan menghasilkan padi yang berlimpah. Hal ini diperkuat dengan pernyataan narasumber Ac. Menurut Ac, ritual yang dilakukan dalam tradisi Baroah itu dilakukan dengan doa-doa sebagai wujud terimakasih kepada Jubata. Selain doa-doa juga dilakukan ritual ngawah untuk memastikan lokasi penanaman baik adanya. Dalam wawancara mendalam pada tanggal 25 Oktober 2019, Ac mengatakan,

"Dalam nyangahatn koa manyak doa nang dingucapant, terutama misalkan untuk acara baroah nian, doa khususnya koa batarima'kasih $\mathrm{ka}^{\prime}$ Jubata karna dah mare' padi nang berlimpah. Ada uga ngawah, kade nang nian dilakukan pas awal sanape batanam padi , nele' nele' lokasi nang maok ditanami padi, ibaratkan survey lokasi" (Dalam nyangahatn itu banyak doa yang diucapkan, misalkan pada acara baroah ini. Doa khususnya itu adalah ucapan terimakasih kepada Jubata karena sudah diberikan padi yang berlimpah. Ada juga ngawah, yang ini dilakukan disaat awal sebelum penanaman padi, melihat-lihat lokasi yang akan ditanami padi nantinya, yang bisa disebut dengan survey lokasi penanaman).

Dalam kehidupan suatu masyarakat, budaya yang diturunkan dari satu generasi kepada generasi berikutnya merupakan suatu usaha untuk menyampaikan pesanpesan, nasihat serta kearifan lokal yang dimiliki oleh masyarakat tersebut kepada generasi berikutnya. Ada makna dari setiap pesan yang disampaikan melalui ajaran maupun ritual yang dilakukan dalam budaya yang mereka hidupi. Mengacu dari pendapay Herbert Blumer, ritual yang dilakukan dalam tradisi Baroah ini juga merupakan media penyampaian pesan dari generasi terdahulu kepada generasi berikutnya yang sarat dengan makna. Menurut Herbert Blumer setiap manusia bertindak terhadap sesuatu berdasarkan makna-makna yang ada pada sesuatu itu bagi mereka. Setiap individu mendapatkan makna ini dari hasil interaksi sosial yang dilakukan dengan orang lain. Makna-makna kemudian disempurnakan pada saat proses interaksi sosial sedang berlangsung (Littlejohn dan Foss, 2012 : 96). Makna sangat dipengaruhi oleh budaya yang dihidupi oleh setiap orang. Menurut Herbert Blumer (dalam Soeprapto 2002: 120), makna dipahami dengan cara bertumpu pada 3 premis utama, yaitu: 
1. Manusia

terhadap

bertindak sesuatu

berdasarkan makna-makna yang ada pada sesuatu itu bagi mereka.

2. Makna itu diperoleh dari hasil interaksi sosial yang dilakukan dengan orang lain.

3. Makna-makna tersebut disempurnakan di saat proses interaksi sosial sedang berlangsung.

Bagi masyarakat di Desa Sompak, ritual yang dilakukan dalam tradisi Baroah sarat dengan makna. Melalui ritual-ritual yang dilakukan, terkandung pesan-pesan yang sarat dengan makna. Pesan secara sederhana diartikan sebagai isi (contect aspect) untuk suatu tujuan mempengaruhi pikiran dan gagasan orang lain. Pesan diwujudkan dalam bentuk lambang, berupa kata-kata, gambar dan tulisan (pesan verbal), dan perilaku nonverbal (Purwasito, 2003). Narasumber Fe dalam wawancara mendalam pada tanggal 22 Oktober 2019 mengatakan,

'Urakng ka' dia koa picaya' kade ahepun rajaki nang atakng koa samua dari Jubata, Jubata samua nang mare' (Masyarakat disini itu percaya jikalau apapun rejeki yang dating itu adalah semua dari Jubata, Jubata semua yang memberi)

Pesan lain yang disampaikan melalui ritual dalam tradisi Baroah adalah bahwa kita sebagai manusia harus hormat kepada Tuhan yang memberi kehidupan. Ac dalam wawancara mendalam pada tanggal 25 Oktober 2019 mengatakan,

"Dari nianlah kami nang urakng tuha koa ngajari kamuda, ahe agik diri nian Talino untuk menghormati Jubata, karena ahepun nang milik diri' koa, kade buke Jubata nang mare' na' mungkin lekoa" (dari inilah kami para orang tua mengajari anakmuda untuk menghormati Jubata, terlebih lagi kita adalah manusia karena apapun yang kita miliki, jikalau bukan Jubata yang memberi tidak mungkin seperti itu)

Ritual dalam tradisi Baroah merupakan satu cara yang digunakan oleh orang tua untuk mengajarkan kepada anakanaknya untuk menghormati Jubata. Tindakan ini dilakukan sebagai wujud penghargaan masyarakat Desa Sompak terhadap tradisi yang diajarkan oleh nenek moyang mereka. Sampai saat ini, masyarakat di Desa Sompak masih menjunjung tinggi budaya yang mereka miliki dan menghargai semua tradisi yang berlaku di masyarakat tersebut. Terkait hal ini, SS dalam wawancara mendalam pada tanggal 29 Oktober 2019 mengatakan,

"Acara nian dari jaman ene' diri' de'e melakukannya, karena diri koa picaya' bahwa ada keturunan Jubata nang udah mare diri padi, maka dari koa ampeatn diri' koa bersyukur bisa makatn nasi, dan lekoalah makanya diri harus menghargai" (Acara ini dari jaman nenek moyang kita sudah melakukannya, karena masyarakat percaya bahwa ada keturunan Jubata yang sudah memberi kita padi, maka dari itu sekarang kita bersyukur bisa makan nasi, dan begitulah sebabnya kita harus menghargai)

Mengacu dari pendapat Herbert Mead, pada premis yang pertama mengatakan 'Manusia bertindak terhadap sesuatu berdasarkan makna-makna yang ada pada sesuatu itu bagi mereka.' Ritual 
yang dilakukan oleh masyarakat di desa Sompak melalui tradisi Baroah ini dilakukan berdasarkan makna Jubata bagi mereka. Jubata yang sudah memberikan berkat kepada mereka melalui hasil panen yang melimpah. Tradisi ini dilakukan oleh masyarakat di desa Sompak untuk mensyukuri setiap berkat yang diberikan, seberapapun hasil panen padi yang mereka dapatkan. Menurut Fe dalam wawancara pada tanggal 22 Oktober 2019 mengatakan,

"Memang dah dari de'e diri" melaksanakan acara nian, samua ditujukan untuk nyukuri ahe nang udah diri' namu man diri' punya. Karena dah turun temurun diri selalu ngada'atn acara nian untuk mensyukuri" (memang sudah dari dahulu kita melaksanakan acara ini, semua ditujukan untuk mensyukuri apa yang sudah kita dapatkan dan kita punya. Karena sudah turun temurun kita selalu mengadakan acara ini untuk mensyukuri)

Selain wujud ucapan syukur, makna lain yang diajarkan melalui Budaya Baroah adalah sikap dan perilaku untuk berbagi dengan sesama. Herbert Mead, pada premis yang kedua dan ketiga dari Interaksi simbolik, mengatakan 'makna itu diperoleh dari hasil interaksi sosial yang dilakukan dengan orang lain; dan maknamakna tersebut disempurnakan di saat proses interaksi sosial sedang berlangsung'. Mengacu dalam pendapat Mead ini, bagi masyarakat di Desa Sompak, makna dari ritual dalam tradisi Baroah diperoleh dari hasil interaksi sosial yang dilakukan dengan orang lain dan disempurnakan pada saat interaksi ini sedang berlangsung. Makna ritual dalam tradisi Baroah bukan hanya sebagai bentuk ucapan syukur, tetapi makna ini terus disempurnakan pada saat interaksi sosial itu berlangsung. Makna tradisi Baroah bukan hanya sebagai ucapan syukur, tetapi juga sebagai wujud kebersamaan dan berbagi dengan sesame. Masyarakat di Desa Sompak mempercayai bahwa ketika mereka berbagi dengan sesame, maka mereka akan mendapatkan kelancaran untuk kedepannya. Salah satu narasumber Ac, dalam wawancara mendalam pada tanggal 25 Oktober 2019 mengatakan,

'Baroah nian mare' nuan diri, samua hasil panen nang diri namu koan hasil dari Jubata harus diri syukuri, karena Jubata marakati' uma diri' koa. Dari koanlah, diri dingajari karena udah namu hasil nang manyak nian, ada baiknya diri' koa bisa membagikan ka sesama diri', misalnya page ataupun ayung dari kampong lain“ (Baroah ini memberitahukan kepada kita, semua hasil panen ang kita dapatkan itu merupakan hasil dari Jubata harus disuyukuri, karena Jubata memberkati sawah kita. Dari situlah, kita diajarkan sebab sudah mendapatkan hasil yang banyak ini, sebaiknya kita bisa membagikan ke sesama kita, misalkan kepada keluarga dekat ataupun teman dari kampung lainnya).

Pemahaman dan kepercayaan masyarakat di Desa Sompak tentang berbagi dengan sesama, membawa pengaruh pada perilaku dan kebiasaan mereka sehari-hari. Masyarakat Dayak di Desa Sompak selalu membagikan hasil yang mereka dapatkan sebagai petani kepada sesama, dengan mempriositaskan pada keluarga dekat terlebih dahulu, baru kepada keluarga yang jauh. Melalui ritual dalam tradisi Baroah, masyarakat Dayak di Desa Sompak bisa bersyukur dan berkumpul bersama orang-orang terdekat 
mereka. Dalam wawancara mendalam pada tanggal 29 Oktober 2019, SS mengatakan,

"Dengan acara nian page
waris samadian koa bisa
bakumpul, diri" bisa sama
sama nikmati hasil nang udah
dimare oleh Jubata,"(dengan
cara ini keluarga dekat kita itu
bisa berkumpul, kita bisa
bersama-sama menikmati hasil
yang sudah diberikan oleh
Jubata)

\section{Citra Desa Sompak berdasarkan} Identitas masyarakat Desa Sompak

Mary Jane Collier (Samovar, Porter dan Daniel, 2003:412) dalam tulisannya tentang identitas budaya dan komunikasi antarbudaya menjelaskan bahwa salah satu karakteristik identitas budaya dan komunikasi antarbudaya adalah persepsi diri. Persepsi diri berpijak pada pengakuan individu dan ascription orang lain. Menurut Collier Ascription (pengakuan) merupakan proses dimana atribut-atribut lain diidentifikasikan pada diri seseorang. Di sisi yang lain, identitas dibentuk oleh pandangan orang lain kepada kita, berdasarkan pada komunikasi yang mereka lakukan dengan kita. Identitas mempunyai komponen-komponen perilaku, kognitif dan afektif. Identitas terdiri dari level-level interpretasi terhadap isi dan hubungan. Ketika seseorang berkomunikasi dengan orang lain, pesan-pesan membawa informasi sebagai implikasi bagi siapa yang dalam kontrol, seberapa dekat perasaan orang yang berbicara satu sama lain, bagaimana rasa permusuhan dan bagaimana mereka mempercayai orang lain.

Mengacu dari pendapat Mary Jane Collier, identitas masyarakat Dayak di
Desa Sompak muncul berdasarkan pada pengakuan individu dan ascription orang lain. Ascription (pengakuan) terjadi ketika atribut-atribut (dalam hal ini bahasa Dayak Kanayatn dan tradisi Baroah) diidentifikasikan pada masyarakat Dayak di Desa Sompak ini. Pandangan orang lain terhadap masyarakat Dayak di desa Sompak juga didasarkan dari komunikasi yang mereka lakukan dengan orang lain. Memahami komunikasi yang dilakukan, bisa dilihat dari pola komunikasi yang terjadi dalam kehidupan masyarakat Dayak di Desa Sompak ini.

Dalam kehidupan sosial, ada suatu pola komunikasi yang terjadi di dlaam masyarakat daerah tersebut. Menurut Hartini dan Kartasaputra (1992 : 301), pola komunikasi merupakan standarisasi dari kumpulan perilaku. Pola komunikasi sebagaimana lazimnya, selalu mengikuti suatu alur atau kaidah tertentu. Kaidah ini juga yang mengatur gaya berkomunikasi dalam konteks sosial. Hubungan bentuk dan fungsi komunikasi ini yang dinamakan pemolaan komunikasi (communication patterning). Leavit dalam Rakhmat (1989 : 184) menyebut jaringan komunikasi untuk menggambarkan pola komunikasi kelompok. Menurut Leavit, Ada lima macam jaringan komunikasi, yaitu jaringan komunikasi roda, rantai, Y, lingkaran dan bintang (all-channel).

Masyarakat di Desa Sompak mempunyai pola komunikasi yang berbeda dengan masyarakat lainnya. Pola komunikasi yang terjadi dalam kehidupan masyarakat Dayak di Desa Sompak adalah pola komunikasi ' $\mathrm{Y}$ ' yang dilakukan secara informal dengan menggunakan Bahasa Dayak Kanayatn. Pada tataran ini, ada opinion leader yang ditempatkan pada setiap peristiwa komunikasi yang 
dilakukan. Hal ini seperti yang dikatakan oleh Ac dalam wawancara mendalam pada tanggal 25 Oktober 2019,

"Kade kadian koa, misalnya ada acara panganten, batalah, ataupun mindahi rumah barahu, dan apapun acara koa, masyarakat dimare nuan dengan cara diatangi' tiap-tiap pintu, masih make cara lekoa. Kade Bahasa ka dian koa damanya pake Tabo' atau ditabo'. Nang nabo' koa pun adalah page waris dari pihak nang bagawe, biasanya uwe'uwe' nang dah bekeluarga" (Kalau disini itu, misalnya ada acara pernikahan, pemberian nama, ataupun memindahi rumah baru, dan apapun acara yang akan dilakukan, masyarakat diberitahukan dengan cara didatangi tiap-tiap rumah, masyarakat masih menggunakan cara tersebut. Kalau disebut dengan istilah disini adalah pakai Tabo' atau ditabo'. Yang nabo' itu juga merupakan keluarga dekat dari pihak yang menyelenggarakan pesta, biasanya ibu-ibu yang sudah berkeluarga)

Ritual yang dilakukan dalam acaraacara adat selalu didasarkan pada kaidahkaidah yang berlaku di masyarakat Desa Sompak. Salah satu kaidah yang berlaku di desa ini adalah pada setiap acara dan ritual yang dilakukan di desa ini, yang menjadi pembicaraan utama (yang menyampaikan pesan) adalah orang yang dituakan di dalam keluarga dekat yang bersangkutan. Hal ini diungkapkan nararumber SS dalam wawancara mendalam pada tanggal 29 Oktober 2019,

"Misal ka' dalam pelaksanaan acara pun, samua jalannya acara koa make Bahasa Dayak Kanayatn, na mungkin na make Bahasa diri'.
Tapi kade nang tukang baromong untuk nyampeatn koa nang dituhakan dari kaluarga koa nang disuruh" (semisal di dalam suatu acarapun, semua jalannya acara tersebut menggunakan Bahasa Dayak Kanayatn, tidak ungkin tiak menggunakan Bahasa tersebut. Tapi orang yang menjadi pembicara untuk menyampaikan adalah yang dituakan dalam keluarga tersebut yang dipersilahkan).

Pola komunikasi masyarakat di Desa Sompak dalam bentuk informal ini dapat dilihat dari tindak komunikasi yang dilakukan sehari-hari melalui tegus sapa. Dalam kehidupan sehari-hari, masyarakat Dayak di Desa Sompak dapat bertegur sapa dengan siapapun tanpa memandang usia. Menurut $\mathrm{Fe}$ (dalam wawancara mendalam pada tanggal 22 Oktober 2019),

"Tiap ari koa, nang sering dimake koa Bahasa Dayak Kanayatn, baik urakng tuha maupun nang muda. Ahe agi' misalkan ampus ka' uma koa pasti samua urakng urakng koa make Bahasa Dayak. Na' paduli tuha muda, kade misalkan kanal koa pasti tetap nyaru' walaupun $k a$ tangah maraga" (Tiap hari itu, yang sering dipakai adalah Bahasa Dayak Kanayatn, baik itu orang tua maupun anak muda. Apalagi misalkan pergi ke sawah itu, pasti semua orangorang menggunakan Bahasa Dayak. Tidak perduli tua maupun muda, tetap menyapa semisalnya ada bertemu di jalan)

Pola komunikasi masyarakat di Desa Sompak menjadi suatu identitas masyarakat yang ada di desa ini. Identitas adalah suatu esensi yang dapat dimaknai melalui tanda selera, kepercayaan, sikap, dan gaya hidup. Identitas dianggap bersifat 
personal sekaligus sosial dan menandai bahwa "kita sama atau berbeda" dengan yang lain (the others) (Kumbara, 2008). Identitas mempunyai komponenkomponen perilaku, kognitif dan afektif. Identitas terdiri dari level-level interpretasi terhadap isi dan hubungan (Mary Jane Collier dalam Samovar, Porter dan Daniel, 2003 : 412) Dalam kehidupan masyarakat Dayak di Desa Sompak, identitas dapat diamati dari perilaku, yaitu perilaku pada saat berkomunikasi maupun perilaku pada saat melakukan ritual tradisi Baroah.

Berdasarkan pada perilaku komunikasi, identitas masyarakat Dayak di Desa Baroah adalah pertama, masyarakat yang memiliki komunikasi yang terstruktur dengan menggunakan opinion leader (yaitu orang yang dituakan). Kedua, komunikasi yang dilakukan secara informal. Ketiga, komunikasi dilakukan dengan menggunakan Bahasa Dayak Kanayatn.

Berdasarkan pada tradiri Baroah, identitas masyarakat Dayak di Desa Sompak dapat dilihat dari perilaku dalam ritual yang dilakukan. Identitas masyarakat Dayak di Desa Sompak berdasarkan ritual dalam tradisi Baroah adalah: pertama, masyarakat Dayak di Desa Sompak adalah masyarakat yang selalu bersyukur kepada Jubata atas semua berkat yang diberikan, atas panen yang mereka peroleh, atas kesehatan dan atas keselamatan dari bencana. Kedua, Masyarakat Dayak di Desa Sompak adalah masyarakat yang berbagi. Ketiga, masyarakat yang suka bergotong royong.

Kehidupan bergotong royong dalam kehidupan sehari-hari masyarakat Dayak yang ada di desa Sompak ini bukan hanya dapat dilihat dari ritual tradisi Baroah, tetapi juga dapat dilihat dalam kehidupan sehari-hari. Kehidupan bergotong royong ini dapat dilihat pada saat masyarakat melaksanakan suatu acara pesta besar. Sikap menghargai antar masyarakat masih sangat kuat di desa Sompak. Hal itu diperkuat dengan pernyataan Ac, salah satu narasumber dalam penelitian ini,

"kade ada sote' keluarga ka' kampong koa manjuat gawe, pasti urakng ka' kampong koa menghargai nang manjuat gawe koa, ada manto' persiapan gawe, bamasak, manto' nyumbang uga'. Dah dari de'e lekoa maan urakng diri' ka kampokng nian"'(Jikalau ada satu keluarga dikampung ini yang membuat acara pesta, pasti masyarakat kampung menghargai yang membuat pesta tersebut, ada yang membantu persiapan pesata, memasak, membantu menyumbang keperluan pesta juga. Sudah dari dulu seperti itu masyarakat di kampung ini).

Pada level afektif, identitas masyarakat Dayak di Desa Sompak ini dapat dilihat dari kepercayaan mereka. Hal ini seperti yang dikatakan oleh $\mathrm{Fe}$, salah satu narasumber dalam penelitian ini,

'Salama' nian, Dayak koa dah terkenal adat istiadatnya, terlebih ritualnya. Nyangahatn koa jak udah masok warisan budaya kabupaten diri'“. (selama ini, Dayak itu sudah terkenal akan adat istiadatnya, terlebih ritualnya. Nyangahatn itu saja sudah masuk menjadi warisan budaya Kabupaten kita)

Masyarakat Dayak dikenal dengan masyarakat yang hidup dengan adat serta nilai-nilai yang dianut dengan berdasarkan adat dari budaya yang mereka hidupi. 
Kecintaan terhadap adat merupakan identitas dari masyarakat Dayak khususnya masyarakat di desa Sompak. Menurut SS, Identitas Masyarakat Desa Sompak itu ada juga pada nilai kehidupannya seperti mencintai adat. Narasumber SS mengatakan bahwa :

"Dari enek koa, kamuda kamuda enek ka kampong dah katelean manyak nang mencintai budayanya. Buktinya ase dah ada acara tari-tarian untuk acara Naik Dango, manyak nang menirukan gerakan, manyak uga nang malatn mainia' alat musik tradisional. Ahe agi' Namanya acara acara ka kampong, pasti na pernah ngalupaan adat. Mindahi' rumah barahu jak pasti make adat, lekoa uga' panganten, kamuda baru' lahir, samua samua make adat" (dari kecil itu, anak-anak kecil di kampung ini sudah terlihat banyak yang mencintai budayanya. Buktinya jikalau sudah ada acara tari-tarian untuk acara Naik Dango, banyak yang menirukan gerakan penari, banyak juga yang sudah inging untuk memainkan alat music tradisional. Apalagi, setiap acara-acara yang dilakukan dalam kampung, pasti tidak pernah melupakan adat)

Jalaludin Rakhmat (1999 : 51), persepsi adalah pengalaman objek, peristiwa atau hubungan-hubungan yang diperoleh dengan menyimpulkan informasi dan menafsirkan pesan. Persepsi memberikan makna pada stimuli inderawi (sensory stimuli). Persepsi merupakan suatu proses yang digunakan oleh setiap individu untuk memberikan makna pada stimuli. Kotler (2002:198) mendefinisikan persepsi sebagai suatu proses yang digunakan oleh individu untuk memiliki, mengorganisasi, dan mengintepretasikan masukan-masukan informasi guna menciptakan gambaran dunia yang memiliki arti. Dengan kata lain, persepsi sangat dipengaruhi oleh proses infomasi yang didapatkan.

Berdasarkan dari pendapat Jalaludin Rakhmat dan Kotler ini, serta mengacu dari pendapat Marry Jane Collier, identitas yang terbangun tentang masyarakat Dayak di Desa Sompak akan membawa pengaruh pada persepsi diri. Persepsi yang dipahami oleh masyarakat Desa Sompak tentang dirinya sendiri, maupun persepsi masyarakat luar tentang identitas masyarakat di desa Sompak. Identitas masyarakat Dayak di Desa Baroah sebagai masyarakat yang memiliki komunikasi yang terstruktur dengan menggunakan opinion leader (yaitu orang yang dituakan), komunikasi yang dilakukan secara informal dan komunikasi dilakukan dengan menggunakan Bahasa Dayak Kanayatn. Serta identitas masyarakat Dayak di Desa Sompak sebagai masyarakat yang selalu bersyukur kepada Jubata, masyarakat yang berbagi dan masyarakat yang suka bergotong royong.

Persepsi tentang masyarakat Dayak di Desa Sompak akan mempengaruhi penilaian masyarakat dan citra masyarakat tentang masyarakat yang ada di desa tersebut. Mengacu dari pendapat Assael, persepsi dari setiap individu akan mempengaruhi perhatian, pemahaman dan retensi. Assael (1992:45) dalam bukunya yang berjudul Consumer Behavior and Marketing action, menyebutkan bahwa "Perception go through three distict phases once the consumer is expose to the stimulus: attention, comprehension and retention”. Stimulus yang berasal dari luar 
individu akan mempengaruhi persepsi individu tersebut dan terjadi proses pembentukan citra. Dengan kata lain, stimulus yang berasal dari luar organisasi (sebut komunitas) akan mempengaruhi citra organisasi (komunitas) tersebut (Soemirat dan Ardianto, 2003:115). Citra merupakan tanggapan masyarakat akan suatu makna (Alma, 2008:54). Makna ini muncul berdasarkan stimulus yang diterima setiap individu. Salah satu citra menurut pendapat Jefkins (2003:20) adalah mirror image (Citra Bayangan). Citra ini adalah citra yang dianut oleh orang dalam mengenai pandangan luar, terhadap organisasinya dan bagaimana tanggapan masyarakat akan perusahaan. Makna atas dari

pengalaman memperoleh informasi dan tanggapan masyarakat.

Dalam kehidupan masyarakat Dayak di Desa Sompak, citra akan terbentuk berdasarkan persepsi yang muncul dari masyarakat yang ada di luar desa tersebut. Sementara persepsi ini terbentuk berdasarkan stimulus yang diterima oleh masyarakat di luar Desa Sompak, berdasarkan identitas diri masyarakat Desa Sompak yang dilihat dari tindak komunikasi dan makna pesan dari ritual tradisi Baroah.

\section{SIMPULAN}

Identitas masyarakat Dayak di Desa Sompak dapat diamati dari perilaku komunikasi dan dari makna pesan melalui ritual tradisi Baroah. Berdasarkan pada perilaku komunikasi, identitas masyarakat Dayak di Desa Baroah adalah pertama, masyarakat yang memiliki komunikasi yang terstruktur dengan menggunakan opinion leader (yaitu orang yang dituakan). Kedua, komunikasi yang dilakukan secara informal. Ketiga, komunikasi dilakukan dengan menggunakan Bahasa Dayak Kanayatn.

Berdasarkan pada tradiri Baroah, identitas masyarakat Dayak di Desa Sompak dapat dilihat dari perilaku dalam ritual yang dilakukan. Identitas masyarakat Dayak di Desa Sompak berdasarkan ritual dalam tradisi Baroah adalah: pertama, masyarakat Dayak di Desa Sompak adalah masyarakat yang selalu bersyukur kepada Jubata atas semua berkat yang diberikan, atas panen yang mereka peroleh, atas kesehatan dan atas keselamatan dari bencana. Kedua, Masyarakat Dayak di Desa Sompak adalah masyarakat yang berbagi. Ketiga, masyarakat yang suka bergotong royong.

Dalam kehidupan masyarakat Dayak di Desa Sompak, citra akan terbentuk berdasarkan persepsi yang muncul dari masyarakat yang ada di luar desa tersebut. Sementara persepsi ini terbentuk berdasarkan stimulus yang diterima oleh masyarakat di luar Desa Sompak, berdasarkan identitas diri masyarakat Desa Sompak yang dilihat dari tindak komunikasi dan makna pesan dari ritual tradisi Baroah.

\section{DAFTAR PUSTAKA}

Alma, Buchori. (2008). Manajemen Pemasaran dan pemasaran Jasa. Bandung : Alfabeta

Ardianto, Soleh Soemirat., dan Elvinaro. (2004). Dasar-dasar Public Relations. Bandung : PT Remaja Rosdakarya

Assael, Hendry. (1992). Consumer Behavior an Marketing Action. Fourth Edition. New York: Kent Publishing Company 
Darmastuti, R., Bajari, A., Martodirdjo, H.

S., \& Maryani, E. (2016). Gethok

Tular, Pola Komunikasi Gerakan

Sosial Berbasis Kearifan Lokal

Masyarakat Samin di Sukolilo.

Jurnal ASPIKOM, 3(1), 104.

https://doi.org/10.24329/aspikom.v

$3 \mathrm{i} 1.103$

Jalaludin Rahmat. (1999). Psikologi

Komunikasi. Bandung : Remaja

Rosdakarya

Jefkins, Frank. (2003). Public Relations.

Edisi kelima. Jakarta : PT G;obal

Aksara Pratama.

Kumbara, A. A. N. A. (2008).

KONSTRUKSI IDENTITAS

ORANG SASAK DI LOMBOK

TIMUR , NUSA TENGGARA

BARAT. 20(3), 315-326.

Kotler, Philip. (2007). Manajemen

Pemasaran. Jilid 1. Edisi Kedua

belas. Alih bahasa

oleh Benyamin Molan. Jakarta: PT.

Indeks.

Littlejohn, Stephen W \& Karen A. Foss.

(2009). Teori Komunikasi, edisi 9.

Jakarta: Salemba Humanika

Lagu, M. (2016). Komunikasi

Antarbudaya Di Kalangan

Mahasiswa Etnik Papua dan Etnik

Manado Di Universitas Sam

Ratulangi Manado. E- Journal

“Acta Diurna," V(3), 1-10.

Mahalli, Z. (2016). Studi Dampak

Tayangan Televisi Terhadap

Perkembangan Perilaku Sosial

Anak. 21-34.

Manab, A. (2008). Penelitian Pendidikan

Pendekatan Kualitatif.

Ngare, F. (2014). Studi Komunikasi

Budaya Tentang Upacara Ritual

Congko Lokap Dan Komunikasi

Dalam Pengembangan Pariwisata aerah Manggarai Provinsi Nusa

Tenggara Timur. Jurnal J-Ika, 1(1), 1-11. Retrieved from

http://ejournal.bsi.ac.id/ejurnal/inde

x.php/jika/article/view/230

Nugrahani, F. (2014). Metode Penelitian

Kualitatif dalam Penelitian

Pendidikan Bahasa. 305.

Priskila, H. (2010). Tradisi Naik Dango

Suku Dayak Kanayatn. Skripsi.

Purwasito,A.(2003).Komunikasi

Multikultural.Cetakan pertama.

Samovar, Larry.A., Richard E.Porter \& Edwin R. McDaniel. (2007). Communication between Cultures 6th Edition,Thomson and Wadsworth Publishing Company, Belmont

California.

Simbolon, D. (2012). MEMAHAMI

KOMUNIKASI BEDA BUDAYA

ANTARA SUKU BATAK TOBA

DENGAN SUKU JAWA DI

KOTA SEMARANG. Экономика

Региона, 10(9), 32.

Tamburian, H. . D. (2018). Komunikasi

Lintas Budaya Masyarakat Dayak

Dalam Menjaga Kerukunan Hidup

Umat Beragama. Jurnal

Komunikasi, 10(1), 77.

https://doi.org/10.24912/jk.v10i1.1

220

Tubbs, Stewart L dan Moss, Sylvia. (1999). Human Communication. 